Article

\title{
An Efficient New Route to Dihydropyranobenzimidazole Inhibitors of HCV Replication
}

\author{
Matthew A. Parker ${ }^{1, *}$, Emily Satkiewicz ${ }^{2}$, Thomas Hermann ${ }^{2}$ and B. Mikael Bergdahl ${ }^{1, *}$ \\ 1 Department of Chemistry and Biochemistry, San Diego State University, San Diego, CA 92182, \\ USA
}

2 Department of Chemistry and Biochemistry, University of California, La Jolla, San Diego, CA 92093, USA

* Authors to whom correspondence should be addressed; E-Mails: parker@sciences.sdsu.edu (M.P.); bergdahl@sciences.sdsu.edu (M.B.); Tel.: +1-619-594-2422.

Received: 15 November 2010; in revised form: 24 December 2010 / Accepted: 28 December 2010 / Published: 30 December 2010

\begin{abstract}
A class of dihydropyranobenzimidazole inhibitors was recently discovered that acts against the hepatitis $\mathrm{C}$ virus (HCV) in a new way, binding to the IRES-IIa subdomain of the highly conserved $5^{\prime}$ untranslated region of the viral RNA and thus preventing the ribosome from initiating translation. However, the reported synthesis of these compounds is lengthy and low-yielding, the intermediates are troublesome to purify, and the route is poorly structured for the creation of libraries. We report a streamlined route to this class of inhibitors in which yields are far higher and most intermediates are crystalline. In addition, a key variable side chain is introduced late in the synthesis, allowing analogs to be easily synthesized for optimization of antiviral activity.
\end{abstract}

Keywords: HCV; benzimidazole; RNA; replication; inhibitor

\section{Introduction}

Hepatitis $\mathrm{C}$ virus (HCV) is an RNA virus which is a very serious human health threat, with an estimated $3 \%$ of the world's population being currently infected [1]. No vaccines are available, and the majority of infected people fail to clear the virus and become chronic carriers [2]. In a significant number of people this condition eventually leads to cirrhosis and liver failure. Such HCV-related liver damage is a leading reason for liver transplantations [3]. 
A new and promising HCV drug target is the HCV RNA itself. In 2005, Seth et al. [4] reported the discovery of a new class of anti-HCV molecules, benzimidazoles that target the virus by binding to a key part of the 5'-untranslated region of the viral RNA known as IRES (Internal Ribosome Entry Site). Recently, Parsons et al. [5] showed that these benzimidazoles inhibit translation initiation through conformational induction. The compounds showed affinity for the HCV RNA as well as inhibitory activity in an HCV replicon assay. The two most potent compounds (Figure 1) possessed an affinity of $0.86 \mu \mathrm{M}$ and $0.72 \mu \mathrm{M}$, respectively, for the key IRES IIa subdomain of the viral RNA [4]. However, the reported synthetic route is lengthy and low-yielding, and the intermediates are troublesome to purify due to the presence of aliphatic amino groups and/or polar side chains. The overall yield of the target compounds is a disappointing $0.6 \%$, making it impractical to synthesize libraries for SAR optimization or to obtain enough material for crystallization studies. Thus, further research into this new mode of anti-HCV activity has been impeded.

Figure 1. Dihydropyranobenzimidazole inhibitors.

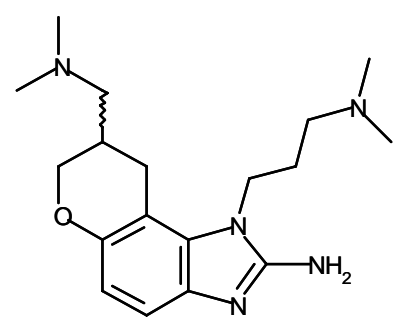

$( \pm)-1$

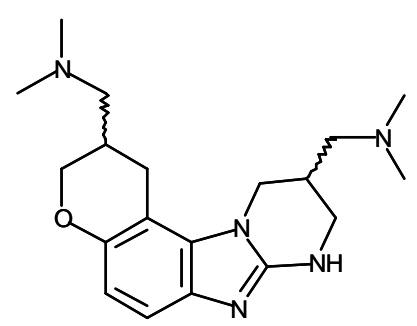

$( \pm)-2 a, 2 b$

(mixture of diastereomers)

In order to circumvent these difficulties and provide access to useful quantities of this class of HCV inhibitors, we have devised a new, efficient synthetic route based on early generation of the chroman nucleus. To avoid difficulties in separating mixtures of diastereomers, we chose to focus our synthetic efforts on a route to $( \pm)-\mathbf{1}$ rather than $( \pm)$-2a,b. Problematic polar functional groups are introduced in protected form so that all intermediates can be easily purified on silica, and the key $\omega$ (dimethylamino)propyl side chain is introduced late in the route, allowing for much easier synthesis of analogous structures for SAR studies.

\section{Results and Discussion}

\subsection{Chemistry}

The first seven steps of the route reported by Seth et al. [4] are devoted to stepwise construction of the chroman nucleus. We saw that a considerably more efficient approach would be to create this ring system at the outset. A literature search revealed that Loiodice et al. [6] had reported the synthesis of a related chromene in good yield by cyclization of the corresponding salicylaldehyde with acrolein under Baylis-Hillman conditions. Thus a route based on the retrosynthetic analysis given below in Figure 2 appeared feasible. 
Figure 2. Retrosynthetic analysis.<smiles>CN(C)CCCn1c(N)nc2ccc3c(c21)CC(CN(C)C)CO3</smiles>

(士)-1<smiles>CN(C)C(=O)C1COc2ccc([N+](=O)[O-])c(Cl)c2C1</smiles>

8<smiles>C=CC1=Cc2c(Cl)cccc2OC1</smiles>

4

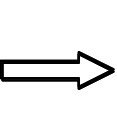

3

Indeed, subjecting readily available 6-chlorosalicylaldehyde 3 [7] to the Baylis-Hillman conditions gave a $72 \%$ yield of the desired chromene aldehyde 4 as a crystalline yellow solid. We were thus encouraged to continue development of our envisioned route as shown below in Scheme 1.

Scheme 1. New route to dihydropyranobenzimidazole inhibitors.

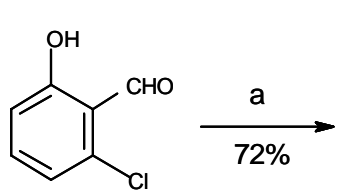

3

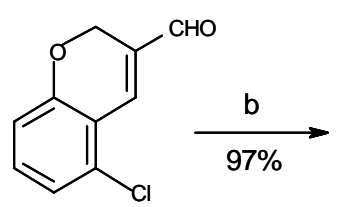

4

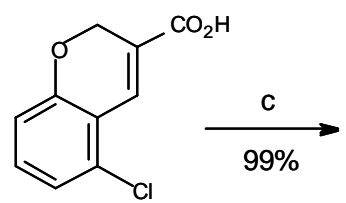

5<smiles>O=C(O)C1COc2cccc(Cl)c2C1</smiles>

6

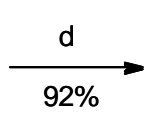<smiles>CN(C)C(=O)C1COc2cccc(Cl)c2C1</smiles>

7<smiles>CN(C)C(=O)C1COc2ccc([N+](=O)[O-])c(Cl)c2C1</smiles>

8<smiles>CN(C)C(=O)C1COc2ccc([N+](=O)[O-])c(NCCCN(C)C(=O)c3ccccc3)c2C1</smiles>

9<smiles>CN(C)C(=O)c1ccccc1C(=O)C1COc2ccc3nc(N)n(CCCN(C)C(=O)OC(C)(C)C)c3c2C1</smiles>

10

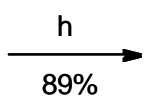<smiles>CN(C)CCCn1c(N)nc2ccc3c(c21)CC(CN(C)C)CO3</smiles>

1

Reagents and conditions: (a) acrolein, $\mathrm{DABCO}, \mathrm{CH}_{3} \mathrm{CN}$; (b) $\mathrm{Ag}_{2} \mathrm{O}, \mathrm{NaOH}, \mathrm{EtOH} / \mathrm{H}_{2} \mathrm{O}$; (c) $\mathrm{Na} / \mathrm{Hg}$, aq. $\mathrm{NaOH}$; (d) EDC, $\mathrm{Me}_{2} \mathrm{NH} . \mathrm{HCl}, \mathrm{HOBt}, \mathrm{N}$-Me-morpholine, $\mathrm{CH}_{2} \mathrm{Cl}_{2}$; (e) $\mathrm{NaNO}_{3}, \mathrm{TFA}$; (f) $\mathrm{H}_{2} \mathrm{~N}\left(\mathrm{CH}_{2}\right)_{3} \mathrm{~N}\left(\mathrm{CH}_{3}\right)$ Boc, NMP; (g) $\mathrm{H}_{2}, \mathrm{Pd} / \mathrm{C}$, EtOH, then BrCN/CH${ }_{3} \mathrm{CN}$; (h) $\mathrm{LiAlH}_{4}$, THF.

The next two steps also take advantage of methods described by Loiodice et al. in the previously cited reference [6]. Aldehyde 4 was readily oxidized by freshly generated silver oxide to carboxylic acid 5, which was then quite cleanly reduced with sodium amalgam under classical conditions to give an excellent yield of chroman 6. Straightforward EDC-activated coupling of $\mathbf{6}$ with dimethylamine in the presence of $\mathrm{HOBt}$ and $\mathrm{N}$-methylmorpholine according to the method of Yoshikawa et al. [8] proceeded a bit slowly, but gave an excellent yield of amide 7 . 
Nitration with sodium nitrate in trifluoroacetic acid [9] gave a 50\% yield of a 2:1 ratio of the desired isomer $\mathbf{8}$, in which the nitro group is para to the activating alkoxy substituent, and the corresponding ortho-substituted minor isomer. Fortunately, the isomers are easily separable by flash chromatography on silica. An attempt to improve the yield by switching to nitronium tetrafluoroborate $[10,11]$ in sulfolane/acetonitrile reversed the regioselectivity, giving mostly the undesired ortho isomer. The structure of $\mathbf{8}$ was verified by palladium-catalyzed reduction/hydrodechlorination to aniline $\mathbf{1 1}$ (Figure 3), allowing unambiguous assignment of the position of the nitro substituent based on the observation of only one pair of ortho-coupled aryl protons in the NMR spectrum after reduction.

Figure 3. Determination of regiochemistry of nitration based on ${ }^{1} \mathrm{H}-\mathrm{NMR}$ after hydrogenation.

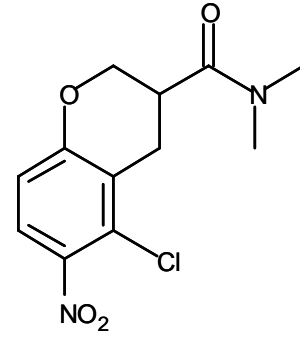

8

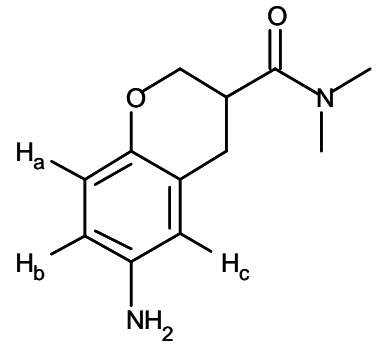

11

$J_{\mathrm{ab}}=8.5 \mathrm{~Hz} ; J_{\mathrm{ac}}, J_{\mathrm{bc}}$ not observed

Nucleophilic aromatic substitution of the activated chloro substituent of $\mathbf{8}$ with commercially available mono-Boc-protected $N$-methyl-1,3-propanediamine [12,13] then gave a nearly quantitative yield of substituted ortho-nitroaniline 9. Adding this side chain at a late point in the synthetic routeonly two steps from the end-provides an opportunity for a divergent synthesis of numerous analogs by employing various primary amines for $\mathrm{S}_{\mathrm{N}} \mathrm{Ar}$ at this point.

Catalytic hydrogenation of $\mathbf{9}$ over palladium/charcoal followed immediately by reaction with cyanogen bromide according to the method of Lo et al. [14] gave a good yield of aminobenzimidazole 10, as all other potential nucleophilic sites in the molecule are protected. Then, in the final step of the route, 10 was treated with lithium aluminum hydride in refluxing THF, simultaneously reducing the dimethylamide moiety to an amine and the Boc group of the aminoalkyl side chain to a methyl group to yield the desired product $( \pm)-\mathbf{1}$. The overall yield over eight steps is $10.7 \%$, better than an order of magnitude improvement over the existing published route.

\subsection{Verification of biochemical activity}

The activity of ( \pm )-1 against the HCV IRES domain IIa RNA target was tested in a previously established fluorescence resonance energy transfer (FRET) assay [5] which detects the opening of the bent loop structure of the IIa RNA upon binding of inhibitors. The measured $\mathrm{EC}_{50}$ was $2.2 \pm 0.4 \mu \mathrm{M}$, which roughly corresponds to the value of $0.82 \mu \mathrm{M}$ reported by Seth et al. [4] for the same compound in a mass spectrometry-based assay. 


\section{Experimental}

\subsection{General}

Experiments were conducted under an argon atmosphere unless stated otherwise. Reagent grade THF was distilled from sodium/benzophenone. Sodium amalgam was prepared as described by McDonald and Reineke [15]. TLC was performed using EMD Silica Gel $60 \mathrm{~F}_{254}$ plates. Highresolution mass spectra were recorded on an Agilent LCTOF high-resolution TOF analyzer with electrospray ionization. Flash chromatography was performed on a Biotage SP1 using prepacked silica columns. Preparative reversed-phase HPLC was performed on a Shimadzu LC-8A HPLC system with

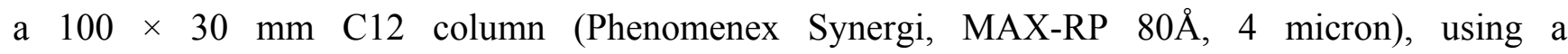
water/methanol $/ 0.1 \%$ formic acid eluent system with a flow rate of $40 \mathrm{~mL} / \mathrm{min}$ and detection at $215 \mathrm{~nm}$ and $280 \mathrm{~nm}$. ${ }^{1} \mathrm{H}-\mathrm{NMR}$ and ${ }^{13} \mathrm{C}$-NMR spectra were recorded at $25{ }^{\circ} \mathrm{C}$ on a Varian VNMRS-400

spectrometer $\left({ }^{1} \mathrm{H}: 400 \mathrm{MHz} ;{ }^{13} \mathrm{C}: 100 \mathrm{MHz}\right)$, with chemical shift values being reported in ppm relative to tetramethylsilane used as an internal standard. Melting points were measured using a Thomas Hoover Uni-Melt melting point determination apparatus and are uncorrected.

\subsection{Synthesis}

5-Chloro-2H-chromene-3-carboxaldehyde (4). A mixture of 6-chlorosalicylaldehyde 3 [7] (16.5 g, $0.105 \mathrm{~mol})$, DABCO (5.90 g, $0.053 \mathrm{~mol})$, acrolein $(10.5 \mathrm{~mL}, 0.158 \mathrm{~mol})$, and dioxane $(36 \mathrm{~mL})$ was placed in a sealed vial and heated with stirring at $95{ }^{\circ} \mathrm{C}$ for 140 minutes. The reaction mixture was cooled to room temperature, diluted with $\mathrm{CH}_{2} \mathrm{Cl}_{2}$, washed with $10 \%$ aqueous $\mathrm{HCl}$ and then brine, dried with anhydrous $\mathrm{Na}_{2} \mathrm{SO}_{4}$, and evaporated. Chromatography on silica using a gradient of $25-50 \%$ $\mathrm{CH}_{2} \mathrm{Cl}_{2}$ in hexanes gave $14.8 \mathrm{~g}(72 \%)$ of 4 as light yellow crystals. An analytical sample was recrystallized from EtOAc/hexanes: m.p. 65.5-66 ${ }^{\circ} \mathrm{C} .{ }^{1} \mathrm{H}-\mathrm{NMR}$ (DMSO- $d_{6}$ ) $\delta 9.69(\mathrm{~s}, \mathrm{CHO}, 1 \mathrm{H}), 7.77$ (s, $\mathrm{CH}=\mathrm{CCHO}, 1 \mathrm{H}), 7.34(\mathrm{dd}, \operatorname{Ar} H, J=8.0,8.0 \mathrm{~Hz}, 1 \mathrm{H}), 7.13(\mathrm{~d}, \operatorname{Ar} H, J=8.0 \mathrm{~Hz}, 1 \mathrm{H}), 6.88(\mathrm{~d}, \operatorname{Ar} H$, $J=8.0 \mathrm{~Hz}, 1 \mathrm{H}), 4.94\left(\mathrm{~s}, \mathrm{OCH}_{2}, 2 \mathrm{H}\right) .{ }^{13} \mathrm{C}-\mathrm{NMR}\left(\mathrm{CDCl}_{3}\right) \delta 189.7,157.1,137.0,133.8,133.0,132.3$, 122.6, 119.2, 115.3, 63.0. HRMS (M+H) ${ }^{+}$: calc. for $\mathrm{C}_{10} \mathrm{H}_{8} \mathrm{O}_{2} \mathrm{Cl}, 195.0207$; found, 195.0204 .

5-Chloro-2H-chromene-3-carboxylic acid (5). To absolute ethanol (195 mL) in a round-bottomed flask was added a solution of sodium hydroxide $(12.2 \mathrm{~g}, 305 \mathrm{mmol})$ in water $(97 \mathrm{~mL})$. A solution of silver nitrate $(27.2 \mathrm{~g}, 160 \mathrm{mmol})$ in water $(97 \mathrm{~mL})$ was then added dropwise with vigorous stirring. To the resulting suspension of $\mathrm{Ag}_{2} \mathrm{O}$ was added aldehyde 4 (14.8 g), and the mixture was heated and stirred at $85{ }^{\circ} \mathrm{C}$ for 75 minutes. The mixture was cooled to room temperature and the clear supernatant was decanted. The solid was washed with a 1:1 ethanol/water solution $(3 \times 20 \mathrm{~mL})$, and the washings were combined with the decanted supernatant. Dilution with an excess of $1 \mathrm{M}$ aq. $\mathrm{HCl}$ gave a voluminous white precipitate which dissolved upon extraction with $\mathrm{CH}_{2} \mathrm{Cl}_{2}$. The resulting $\mathrm{CH}_{2} \mathrm{Cl}_{2}$ solution was dried with $\mathrm{Na}_{2} \mathrm{SO}_{4}$, filtered, and evaporated to give $15.5 \mathrm{~g}(97 \%)$ of 5 as cream-colored fluffy crystals. An analytical sample was recrystallized from EtOAc/hexanes: m.p. 192.5-193 ${ }^{\circ} \mathrm{C} .{ }^{1} \mathrm{H}-\mathrm{NMR}$ (DMSO$\left.d_{6}\right) \delta 13.10\left(\mathrm{bs}, \mathrm{CO}_{2} \mathrm{H}, 1 \mathrm{H}\right), 7.54(\mathrm{~m}, \mathrm{CH}=\mathrm{CCHO}, 1 \mathrm{H}), 7.28(\mathrm{dd}, \mathrm{ArH}, J=8.2,8.2 \mathrm{~Hz}, 1 \mathrm{H}), 7.09$ (dd, $\operatorname{Ar} H, J=8.2,1.1 \mathrm{~Hz}, 1 \mathrm{H}), 6.87(\mathrm{ddd}, \operatorname{Ar} H, J=8.2,1.1,1.1 \mathrm{~Hz}, 1 \mathrm{H}), 4.92\left(\mathrm{~s}, \mathrm{OCH}_{2}, 2 \mathrm{H}\right) .{ }^{13} \mathrm{C}-\mathrm{NMR}$ 
$\left(\mathrm{CDCl}_{3}\right) \delta 168.7,156.6,133.8,132.3,132.1,122.7,122.5,119.4,115.1,64.0$. HRMS $(\mathrm{M}-\mathrm{H})^{-}$: calc. for $\mathrm{C}_{10} \mathrm{H}_{6} \mathrm{O}_{3} \mathrm{Cl}$, 209.0011; found, 209.0012.

5-Chlorochroman-3-carboxylic acid (6). To a solution of 5 (7.50 g) in 10\% aqueous $\mathrm{NaOH}(193 \mathrm{~mL})$ was added 3\% sodium amalgam (103 g) [15]. The mixture was stirred overnight at room temperature. The supernatant was decanted from the liquid mercury, and the mercury was washed twice with small portions of $10 \%$ aq. $\mathrm{NaOH}$. The washings were combined with the supernatant, acidified to a $\mathrm{pH}$ of 2 with conc. $\mathrm{HCl}$, and extracted with $\mathrm{CH}_{2} \mathrm{Cl}_{2}$. The $\mathrm{CH}_{2} \mathrm{Cl}_{2}$ solution was dried with $\mathrm{Na}_{2} \mathrm{SO}_{4}$, filtered, and evaporated to give $7.51 \mathrm{~g}(99 \%)$ of 6 as a white crystalline solid. An analytical sample was recrystallized from EtOAc/hexanes: m.p. $129.5-130{ }^{\circ} \mathrm{C} .{ }^{1} \mathrm{H}-\mathrm{NMR}\left(\mathrm{DMSO}-d_{6}\right) \delta 12.70\left(\mathrm{bs}, \mathrm{CO}_{2} H, 1 \mathrm{H}\right)$, 7.10 (dd, $\operatorname{Ar} H, J=8.0,8.0 \mathrm{~Hz}, 1 \mathrm{H}), 6.99$ (dd, $\operatorname{Ar} H, J=8.0,1.2 \mathrm{~Hz}, 1 \mathrm{H}), 6.75$ (dd, $\operatorname{Ar} H, J=8.0$, $1.2 \mathrm{~Hz}, 1 \mathrm{H}), 4.28\left(\mathrm{dd}, \mathrm{OCH}_{2} \mathrm{CH}, J=10.8,4.3 \mathrm{~Hz}, 1 \mathrm{H}\right), 4.16\left(\mathrm{dd}, \mathrm{OCH}_{2} \mathrm{CH}, J=10.8,7.0 \mathrm{~Hz}, 1 \mathrm{H}\right), 3.05$ $\left(\mathrm{m}, \mathrm{CHCO}_{2} \mathrm{H}, 1 \mathrm{H}\right), 2.90\left(\mathrm{~d}, \mathrm{ArCH}_{2} \mathrm{CH}, J=6.6 \mathrm{~Hz}, 2 \mathrm{H}\right) .{ }^{13} \mathrm{C}-\mathrm{NMR}\left(\mathrm{CDCl}_{3}\right) \delta 178.3,155.2,134.6,127.8$, 121.7, 119.0, 115.4, 65.8, 38.2, 25.4. HRMS (M-H) : calc. for $\mathrm{C}_{10} \mathrm{H}_{8} \mathrm{O}_{3} \mathrm{Cl}$, 211.0167; found, 211.0166.

5-Chloro-N,N-dimethylchroman-3-carboxamide (7). A mixture of 6 (1.50 g, $7.06 \mathrm{mmol})$, dimethylamine hydrochloride (1.44 g, $17.6 \mathrm{mmol})$, HOBt (1.43 g, $10.6 \mathrm{mmol}), N$-methylmorpholine (3.88 $\mathrm{mL}, 35.3 \mathrm{mmol})$, and EDC hydrochloride $(2.03 \mathrm{~g}, 10.6 \mathrm{mmol})$ in dichloromethane $(65 \mathrm{~mL})$ was stirred at room temperature for 50 hours. The reaction mixture was diluted with additional $\mathrm{CH}_{2} \mathrm{Cl}_{2}$, and an equal volume of saturated aq. $\mathrm{NaHCO}_{3}$ was added. The $\mathrm{CH}_{2} \mathrm{Cl}_{2}$ phase was separated, and the aqueous phase was washed $3 \times$ with $\mathrm{CH}_{2} \mathrm{Cl}_{2}$. The $\mathrm{CH}_{2} \mathrm{Cl}_{2}$ phases were combined, dried with $\mathrm{Na}_{2} \mathrm{SO}_{4}$, and evaporated. Chromatography on silica (25-75\% EtOAc in hexanes) gave $1.56 \mathrm{~g}(92 \%)$ of 7 as a pale yellow oil. ${ }^{1} \mathrm{H}-\mathrm{NMR}\left(\mathrm{DMSO}-d_{6}\right) \delta 7.12(\mathrm{dd}, \mathrm{Ar}-H, J=8.2,8.0 \mathrm{~Hz}, 1 \mathrm{H}), 7.01$ (dd, Ar- $H, J=8.0$, $1.1 \mathrm{~Hz}, 1 \mathrm{H}), 6.79(\mathrm{dd}, \mathrm{Ar}-\mathrm{H}, J=8.2,1.1 \mathrm{~Hz}, 1 \mathrm{H}), 4.31\left(\mathrm{~m}, \mathrm{OCH}_{2} \mathrm{CH}, 1 \mathrm{H}\right), 3.84\left(\mathrm{dd}, \mathrm{OCH}_{2} \mathrm{CH}\right.$, $J=10.8,10.8 \mathrm{~Hz}, 1 \mathrm{H}), 3.37-3.30$ (m, partly hidden, $\mathrm{CHCONMe} 2,1 \mathrm{H}), 3.11\left(\mathrm{~s}, \mathrm{NCH}_{3}, 3 \mathrm{H}\right), 2.89$ (dd, partly hidden, $\left.\mathrm{ArCH}_{2} \mathrm{CH}, J=16.8,5.7 \mathrm{~Hz}, 1 \mathrm{H}\right), 2.86\left(\mathrm{~s}, \mathrm{NCH}_{3}, 3 \mathrm{H}\right), 2.79\left(\mathrm{dd}, \mathrm{ArCH}_{2} \mathrm{CH}, J=16.8\right.$, $10.2 \mathrm{~Hz}, 1 \mathrm{H}) .{ }^{13} \mathrm{C}-\mathrm{NMR}\left(\mathrm{CDCl}_{3}\right) \delta 171.7,155.3,134.6,127.6,121.3,119.9,115.2,67.0,37.2,35.6$, 35.4, 26.9. HRMS $(\mathrm{M}+\mathrm{H})^{+}$: calc. for $\mathrm{C}_{12} \mathrm{H}_{15} \mathrm{NO}_{2} \mathrm{Cl}$, 240.0786; found, 240.0792 .

5-Chloro-N,N-dimethyl-6-nitrochroman-3-carboxamide (8). Sodium nitrate (510 $\mathrm{mg}, 6.00 \mathrm{mmol})$ was added to a flask containing trifluoroacetic acid $(37.5 \mathrm{~mL})$ at $0{ }^{\circ} \mathrm{C}$. After stirring for 10 minutes, the mixture was cooled to $-15{ }^{\circ} \mathrm{C}$ (by adding small pieces of dry ice to acetone in a Dewar bath) whereupon the solvent began to freeze. With stirring, a solution of 7 (1.25 g, $5.21 \mathrm{mmol})$ in trifluoroacetic acid $(12.5 \mathrm{~mL})$ was added dropwise. An insulating cover was then placed over the Dewar and the mixture was stirred and allowed to warm very slowly to $18{ }^{\circ} \mathrm{C}$ over 12 hours. The resulting red solution was quenched with ice, diluted with water, and extracted with dichloromethane. The dichloromethane phase was washed with water, then $5 \%$ aq. $\mathrm{KH}_{2} \mathrm{PO}_{4}$ until the $\mathrm{pH}$ of the aqueous wash was 4 to 5 . The dichloromethane phase was dried with $\mathrm{Na}_{2} \mathrm{SO}_{4}$ and evaporated. The resulting residue was purified on silica (25-75\% EtOAc in hexanes) to give $510 \mathrm{mg}(34 \%)$ of $\mathbf{8}$ as a yellow oil. ${ }^{1} \mathrm{H}-\mathrm{NMR}\left(\mathrm{DMSO}-d_{6}\right) \delta 7.86(\mathrm{~d}, \mathrm{Ar}-H, J=9.0 \mathrm{~Hz}, 1 \mathrm{H}), 7.00(\mathrm{~d}, \mathrm{Ar}-H, J=9.0 \mathrm{~Hz}, 1 \mathrm{H}), 4.39$ (m, $\left.\mathrm{OCH}_{2} \mathrm{CH}, 1 \mathrm{H}\right), 4.01$ (dd, $\left.\mathrm{OCH}_{2} \mathrm{CH}, J=11.0,8.8 \mathrm{~Hz}, 1 \mathrm{H}\right), 3.40\left(\mathrm{~m}, \mathrm{CHCO}_{2} \mathrm{H}, 1 \mathrm{H}\right), 3.10\left(\mathrm{~s}, \mathrm{NCH}_{3}\right.$, $3 \mathrm{H}), 2.88\left(\mathrm{dd}, \mathrm{ArCH}_{2} \mathrm{CH}, J=17.0,5.3 \mathrm{~Hz}, 1 \mathrm{H}\right), 2.85$ (s, $\left.\mathrm{NCH}_{3}, 3 \mathrm{H}\right), 2.84$ (dd, partly hidden, 
$\left.\mathrm{ArCH}_{2} \mathrm{CH}, J=17.0,9.2 \mathrm{~Hz}, 1 \mathrm{H}\right) .{ }^{13} \mathrm{C}-\mathrm{NMR}\left(\mathrm{CDCl}_{3}\right) \delta 170.8,158.2,141.6,128.7,124.9,122.1,115.4$, $67.4,37.3,35.7,34.7,27.3$. The undesired minor ortho isomer, which eluted just before compound $\mathbf{8}$, was also isolated: $250 \mathrm{mg}(17 \%)$ of 5-chloro- $N, N$-dimethyl-8-nitrochroman-3-carboxamide as a pale yellow oil, ${ }^{1} \mathrm{H}-\mathrm{NMR}$ (DMSO- $\left.d_{6}\right) \delta 7.79(\mathrm{~d}, \mathrm{Ar}-H, J=8.8 \mathrm{~Hz}, 1 \mathrm{H}), 7.21(\mathrm{~d}, \mathrm{Ar}-H, J=8.8 \mathrm{~Hz}, 1 \mathrm{H}), 4.48$ $\left(\mathrm{m}, \mathrm{OCH}_{2} \mathrm{CH}, 1 \mathrm{H}\right), 4.06\left(\mathrm{dd}, \mathrm{OCH}_{2} \mathrm{CH}, J=10.9,9.1 \mathrm{~Hz}, 1 \mathrm{H}\right), 3.46\left(\mathrm{~m}, \mathrm{CHCO}_{2} \mathrm{H}, 1 \mathrm{H}\right), 3.11\left(\mathrm{~s}, \mathrm{NCH}_{3}\right.$, $3 \mathrm{H}), 2.95\left(\mathrm{dd}, \mathrm{ArCH}_{2} \mathrm{CH}, J=17.0,5.8 \mathrm{~Hz}, 1 \mathrm{H}\right), 2.86\left(\mathrm{~s}, \mathrm{NCH}_{3}, 3 \mathrm{H}\right), 2.86$ (dd, partly hidden, $\left.\mathrm{ArCH}_{2} \mathrm{CH}, J=16.7,10.0 \mathrm{~Hz}, 1 \mathrm{H}\right) .{ }^{13} \mathrm{C}-\mathrm{NMR}\left(\mathrm{CDCl}_{3}\right) \delta 170.5,149.3,139.8,137.6,124.0,123.1$, 120.6, 67.8, 37.2, 35.7, 34.4, 27.2.

tert-Butyl N-[3-[[3-(dimethylcarbamoyl)-6-nitrochroman-5-yl]amino]propyl]-N-methylcarbamate (9). A mixture of 8 (300 mg, $1.05 \mathrm{mmol})$, tert-butyl $N$-(3-aminopropyl)- $N$-methylcarbamate (989 $\mathrm{mg}$, $5.25 \mathrm{mmol}$ ), and $\mathrm{N}$-methylpyrrolidinone $\left(989 \mathrm{mg}\right.$ ) was heated in a sealed tube at $75{ }^{\circ} \mathrm{C}$ for 22 hours. The reaction mixture was diluted with $\mathrm{Et}_{2} \mathrm{O}(75 \mathrm{~mL})$ and washed with $\mathrm{H}_{2} \mathrm{O}(4 \times 75 \mathrm{~mL})$ and $5 \%$ aq. $\mathrm{KH}_{2} \mathrm{PO}_{4}(75 \mathrm{~mL})$, then dried with $\mathrm{Na}_{2} \mathrm{SO}_{4}$, filtered, and evaporated. The crude product was purified on silica using a gradient of 40-50\% EtOAc in $\mathrm{CH}_{2} \mathrm{Cl}_{2}$ to give $399 \mathrm{mg}$ (87\%) of 9 as a bright yelloworange oil. ${ }^{1} \mathrm{H}-\mathrm{NMR}$ (DMSO- $\left.d_{6}\right) \delta 7.82(\mathrm{~d}, \mathrm{Ar}-H, J=9.4 \mathrm{~Hz}, 1 \mathrm{H}), 7.20(\mathrm{~b}, \mathrm{~N} H, 1 \mathrm{H}), 6.35$ (d, Ar- $H$, $J=9.4 \mathrm{~Hz}, 1 \mathrm{H}), 4.37\left(\mathrm{~m}, \mathrm{OCH}_{2} \mathrm{CH}, 1 \mathrm{H}\right), 3.93\left(\mathrm{dd}, \mathrm{OCH}_{2} \mathrm{CH}, J=10.6,10.6 \mathrm{~Hz}, 1 \mathrm{H}\right), 3.25$ (m, partly hidden, $\left.\mathrm{CHCO}_{2} \mathrm{H}, 1 \mathrm{H}\right), 3.25-3.10\left(\mathrm{~m}, 2 \times \mathrm{NCH}_{2}, 4 \mathrm{H}\right), 3.06\left(\mathrm{~s}, \mathrm{NCH}_{3}, 3 \mathrm{H}\right), 2.85\left(\mathrm{~s}, \mathrm{NCH}_{3}, 3 \mathrm{H}\right), 2.80-$ 2.70 (m, partly hidden, $\left.\mathrm{ArCH} \mathrm{H}_{2} \mathrm{CH}, 2 \mathrm{H}\right), 2.71$ (s, $\left.\mathrm{NCH}_{3}, 3 \mathrm{H}\right), 1.70$ (qu, $\mathrm{CH}_{2} \mathrm{CH}_{2} \mathrm{CH}_{2}, J=6.8 \mathrm{~Hz}, 2 \mathrm{H}$ ), $1.34\left(\mathrm{~s}, t\right.$-Bu, 9H). ${ }^{13} \mathrm{C}-\mathrm{NMR}\left(\mathrm{CDCl}_{3}\right) \delta 171.4,160.1,155.7,148.8,131.6,126.5,111.0,109.3,79.6$, $77.2,67.4,45.8,37.3,35.7,35.3,34.4,29.4,28.5,27.9$. HRMS $(\mathrm{M}+\mathrm{H})^{+}$: calc. for $\mathrm{C}_{21} \mathrm{H}_{33} \mathrm{~N}_{4} \mathrm{O}_{6}$, 437.2395; found, 437.2401 .

tert-Butyl N-[3-[2-amino-8-(dimethylcarbamoyl)-8,9-dihydro-7H-pyrano[2,3-g]benzimidazol-1-yl]propyl]-N-methylcarbamate (10). To a flask containing $10 \%$ palladium on carbon $(180 \mathrm{mg})$ was added a solution of 9 (187 $\mathrm{mg}, 0.43 \mathrm{mmol})$ in absolute ethanol $(20 \mathrm{~mL})$. The mixture was stirred for 90 minutes under 1 atmosphere of hydrogen at room temperature, at which point ${ }^{1} \mathrm{H}-\mathrm{NMR}$ analysis showed complete reduction to the corresponding aniline derivative. The mixture was filtered through Celite. The Celite was washed with three 5-mL aliquots of acetonitrile and all filtrates were combined. To this solution was added cyanogen bromide $(49 \mathrm{mg})$ in acetonitrile $(2 \mathrm{~mL})$, and the mixture was stirred at room temperature for 15 hours under argon. The solvent was evaporated, and the residue was dissolved in DMSO $(1 \mathrm{~mL})$ and purified by preparative HPLC using a gradient of 5-50\% methanol/water/0.1\% formic acid over 15 minutes, followed by a ramp to $100 \%$ methanol $/ 0.1 \%$ formic acid over 3 minutes. The fractions containing the major peak were combined and neutralized with aq. $\mathrm{NaHCO}_{3}$. Most of the methanol was evaporated in vacuo, and the resulting aqueous phase was extracted with $\mathrm{CH}_{2} \mathrm{Cl}_{2}$. Drying with $\mathrm{Na}_{2} \mathrm{SO}_{4}$, filtration, and evaporation gave $119 \mathrm{mg}(64 \%)$ of 10 as a nearly colorless oil which solidified into a light tan crystalline solid. An analytical sample was recrystallized from EtOAc/hexanes: m.p. $165.5-166{ }^{\circ} \mathrm{C} .{ }^{1} \mathrm{H}-\mathrm{NMR}$ (DMSO- $d_{6}$ ) $\delta 6.86$ (d, Ar- $H$, $J=8.4 \mathrm{~Hz}, 1 \mathrm{H}), 6.43(\mathrm{~d}, \mathrm{Ar}-H, J=8.4 \mathrm{~Hz}, 1 \mathrm{H}), 6.09$ (bs, Ar-NH$\left.H_{2}, 2 \mathrm{H}\right), 4.23\left(\mathrm{dd}, \mathrm{OCH}_{2} \mathrm{CH}, J=10.6\right.$, $2.93 \mathrm{~Hz}, 1 \mathrm{H}), 4.03$ (bm, $\left.\mathrm{NCH}_{2} \mathrm{CH}_{2}, 2 \mathrm{H}\right), 3.78$ (dd, $\left.\mathrm{OCH}_{2} \mathrm{CH}, J=10.4,10.4 \mathrm{~Hz}, 1 \mathrm{H}\right), 3.35-3.10$ (m, major overlap, $\left.\mathrm{CHCONMe}, \mathrm{ArCH}_{2} \mathrm{CH}, \mathrm{CH}_{2} \mathrm{NMe}, 5 \mathrm{H}\right), 3.12$ (s, $\left.\mathrm{NCH}_{3}, 3 \mathrm{H}\right), 2.88\left(\mathrm{~s}, \mathrm{NCH}_{3}, 3 \mathrm{H}\right), 2.76$ (s, $\mathrm{NCH}_{3}, 3 \mathrm{H}$ ), 1.81 (m, $\left.\mathrm{CH}_{2} \mathrm{CH}_{2} \mathrm{CH}_{2}, 2 \mathrm{H}\right), 1.33$ (bs, $t$-Bu, 9H). ${ }^{13} \mathrm{C}-\mathrm{NMR}$ (DMSO- $d_{6}$ ) $\delta 171.9,154.9$, 
148.1, 137.1, 132.0, 114.1, 109.9, 104.5, 78.9, 66.6, 46.2, 45.7, 41.6, 37.2, 35.5, 35.2, 34.1, 29.3, 28.4, 24.3. HRMS $(\mathrm{M}+\mathrm{H})^{+}$: calc. for $\mathrm{C}_{22} \mathrm{H}_{34} \mathrm{~N}_{5} \mathrm{O}_{4}, 432.2605$; found, 432.2621 .

6-Amino-N,N-dimethylchroman-3-carboxamide (11). Compound 8 (42 mg) was dissolved in absolute ethanol $(10 \mathrm{~mL})$ and stirred with $10 \%$ palladium on carbon $(65 \mathrm{mg})$ under 1 atm of hydrogen at $50{ }^{\circ} \mathrm{C}$ for 3 hours. The mixture was filtered through Celite, and the absorbent was washed several times with ethanol. The combined filtrates were evaporated to give a quantitative yield of $\mathbf{1 1}$ as a tan solid. ${ }^{1} \mathrm{H}-$ NMR (DMSO-d $\left.)_{6}\right) 8.71$ (bs, Ar-NH$\left.H_{2}, 2 \mathrm{H}\right), 6.86(\mathrm{~s}, \mathrm{Ar}-H, 1 \mathrm{H}), 6.84(\mathrm{~d}, \mathrm{Ar}-H, J=8.5 \mathrm{~Hz}, 1 \mathrm{H}), 6.73(\mathrm{~d}$, $\operatorname{Ar}-H, J=8.5 \mathrm{~Hz}, 1 \mathrm{H}), 4.26\left(\mathrm{~m}, \mathrm{OCH}_{2} \mathrm{CH}, 1 \mathrm{H}\right), 3.81\left(\mathrm{dd}, \mathrm{OCH}_{2} \mathrm{CH}, J=10.9,10.0 \mathrm{~Hz}, 1 \mathrm{H}\right), 3.23(\mathrm{~m}$, $\left.\mathrm{CHCO}_{2} \mathrm{H}, 1 \mathrm{H}\right), 3.08\left(\mathrm{~s}, \mathrm{NCH}_{3}, 3 \mathrm{H}\right), 2.86$ (dd, partly hidden, $\left.\mathrm{ArCH}_{2} \mathrm{CH}, J=16.1,10.6 \mathrm{~Hz}, 1 \mathrm{H}\right), 2.84$ (s, $\left.\mathrm{NCH}_{3}, 3 \mathrm{H}\right), 2.79$ (dd, $\left.\mathrm{ArCH}_{2} \mathrm{CH}, J=16.4,5.4 \mathrm{~Hz}, 1 \mathrm{H}\right)$.

8-(Dimethylaminomethyl)-1-(3-dimethylaminopropyl)-8,9-dihydro-7H-pyrano[3,2-e]benzimidazol-2amine (1). Compound 10 (100 mg, $0.232 \mathrm{mmol})$ was dissolved in THF (5 mL) under argon. Lithium aluminum hydride $\left(333 \mathrm{mg}, 8.77 \mathrm{mmol}\right.$ ) was added and the mixture was stirred at $60{ }^{\circ} \mathrm{C}$ for 1.5 hours, then quenched by careful dropwise addition of $3 \mathrm{M}$ aq. $\mathrm{NaOH}$. The solids were filtered off and washed with THF. The filtrate and washings were combined, dried with $\mathrm{Na}_{2} \mathrm{SO}_{4}$, and evaporated to give a tan solid, which was triturated with a minimal amount of EtOAc to give $68 \mathrm{mg}$ (89\%) of $\mathbf{1}$ as an off-white crystalline solid: m.p. $179.5-180.5^{\circ} \mathrm{C} .{ }^{1} \mathrm{H}-\mathrm{NMR}\left(\mathrm{DMSO}-d_{6}\right) \delta 6.83(\mathrm{~d}, \mathrm{Ar}-H, J=8.4 \mathrm{~Hz}, 1 \mathrm{H}), 6.39(\mathrm{~d}$, $\operatorname{Ar}-H, J=8.4 \mathrm{~Hz}, 1 \mathrm{H}), 6.14$ (bs, $\left.\mathrm{Ar}-\mathrm{N} H_{2}, 2 \mathrm{H}\right), 4.13$ (d, OCH $\left.\mathrm{CH}_{2}, J=9.4 \mathrm{~Hz}, 1 \mathrm{H}\right), 4.04$ (dd, $\left.\mathrm{NCH}_{2} \mathrm{CH}_{2}, J=6.9,6.9 \mathrm{~Hz}, 2 \mathrm{H}\right), 3.72\left(\mathrm{dd}, \mathrm{OCH}_{2} \mathrm{CH}, J=10.2,7.2 \mathrm{~Hz}, 1 \mathrm{H}\right), 3.16\left(\mathrm{dd}, \mathrm{ArCH} \mathrm{CH}_{2}\right.$, $J=16.0,4.5 \mathrm{~Hz}, 1 \mathrm{H}), 2.76\left(\mathrm{dd}, \mathrm{ArCH}_{2} \mathrm{CH}, J=16.0,7.2 \mathrm{~Hz}, 1 \mathrm{H}\right), 2.30-2.20$ (m, major overlap, $\left.\mathrm{CHCONMe}_{2}, 2 \times \mathrm{CH}_{2} \mathrm{NMe}_{2}, 5 \mathrm{H}\right), 2.17\left(\mathrm{~s}, \mathrm{NMe}_{2}, 6 \mathrm{H}\right), 2.16\left(\mathrm{~s}, \mathrm{NMe}_{2}, 6 \mathrm{H}\right), 1.80\left(\mathrm{~m}, \mathrm{CH}_{2} \mathrm{CH}_{2} \mathrm{CH}_{2}, 2 \mathrm{H}\right)$. ${ }^{13} \mathrm{C}-\mathrm{NMR}\left(\mathrm{CDCl}_{3}\right) \delta 155.2,149.1,136.7,132.2,115.1,110.9,104.0,68.5,61.8,53.8,46.0,44.4,39.9$, 30.6, 29.0, 25.6. HRMS $(\mathrm{M}+\mathrm{H})^{+}$: calc. for $\mathrm{C}_{18} \mathrm{H}_{30} \mathrm{~N}_{5} \mathrm{O}$, 332.2445; found, 332.2453.

\subsection{FRET assay}

The FRET assay was conducted using a cyanine dye-labeled HCV IRES domain IIa RNA construct as previously described [5]. Briefly, the RNA construct was titrated with increasing amounts of compound 1 and the dose response of the FRET efficiency was recorded. Titrations were performed in triplicate. Fitting of the average FRET signal at each concentration of compound to a one-site binding model resulted in an $\mathrm{EC}_{50}$ of $2.2 \pm 0.4 \mu \mathrm{M}$ for compound 1 binding to the IIa target.

\section{Conclusions}

We have achieved an efficient new synthesis of the potent HCV inhibitor $( \pm)-\mathbf{1}$ in eight steps and $10.7 \%$ overall yield from readily available 6-chlorosalicylaldehyde. This represents better than a fifteen-fold improvement over the published route. In addition, most intermediates are crystalline and easily purified. The high efficiency of the new route combined with the late-stage introduction of the aminoalkyl side chain enables the practical and rapid generation of analogs for SAR studies. We are currently generating new analogs using this route and will report our findings in a subsequent publication. 


\section{Acknowledgements}

We thank Zach Scott and Tim Slugocki for assistance with compound characterization, Dr. LeRoy Lafferty for NMR support, and ChemDiv, Inc., for a generous donation of equipment and supplies. This work was funded in part by the San Diego State University Research Foundation and by the National Institutes of Health, grant R01 AI72021 (T.H.).

\section{References}

1. Hepatitis C fact sheet, World Health Organization, Geneva, Switzerland, 2002.

2. EASL International Consensus Conference on Hepatitis C. Consensus Statement. J. Hepatol. 1999, 31, 3-8.

3. Houghton, M. Hepatitis C viruses. In Fields Virology, 3rd ed.; Fields, B.N., Knipe, D.M., Howley, P.M., Eds.; Lippincott-Raven: Philadelphia, PA, USA, 1996; pp. 1035-1058.

4. Seth, P.P.; Miyaji, A.; Jefferson, E.A.; Sannes-Lowery, K.A.; Osgood, S.A.; Propp, S.S.; Ranken, R.; Massire, C.; Sampath, R.; Ecker, D.J.; Swayze, E.E.; Griffey, R.H.. SAR by MS: Discovery of a new class of RNA-binding small molecules for the Hepatitis $\mathrm{C}$ virus: Internal Ribosome Entry Site IIA Subdomain. J. Med. Chem. 2005, 48, 7099-7102.

5. Parsons, J.; Castaldi, M.P.; Dutta, S.; Dibrov, S.M.; Wyles, D.L.; Hermann, T. Conformational inhibition of the hepatitis $\mathrm{C}$ virus internal ribosome entry site RNA. Nat. Chem. Biol. 2009, 5, 823-825.

6. Loiodice, F; Longo, A; Bianco, P; Tortorella, V. 6-Chloro-2,3-Dihydro-4H-1-Benzopyran Carboxylic Acids: Synthesis, Optical Resolution and Absolute Configuration. Tetrahedron Asymmetry 1995, 6, 1001-1011.

7. Adams, R.S.; Duffey, M.; Gould, A.E.; Greenspan, P.D.; Kulkarni, B.A.; Vos, T.J. Certain pyrazoline derivatives with kinase inhibitory activity. PCT Int. Appl. 2008079277, 3 July 2008.

8. Yoshikawa, K.; Yokomizo, A.; Naito, H.; Haginoya, N.; Kobayashi, S.; Yoshino, T.; Nagata, T.; Mochizuki, A.; Osanai, K.; Watanabe, K.; Kanno, H.; Ohta, T. Design, synthesis, and SAR of cis1,2-diaminocyclohexane derivatives as potent factor Xa inhibitors. Part I: Exploration of 5-6 fused rings as alternative S1 moieties. Bioorg. Med. Chem. 2009, 17, 8206-8220.

9. Spitzer, U.A.; Stewart, R. Trifluoroacetic acid as a medium for aromatic nitration using sodium nitrate. J. Org. Chem. 1974, 39, 3936-3937.

10. Kuhn, S.J.; Olah, G.A. Aromatic Substitution. VII. Friedel-Crafts Type Nitration of Aromatics. J. Am. Chem. Soc. 1961, 83, 4564-4571.

11. Olah, G.A.; Narang, S.C.; Olah, J.A.; Lammertsma, K. Recent aspects of nitration: New preparative methods and mechanistic studies (A Review). Proc. Natl. Acad. Sci. USA 1982, 79, 4487-4494.

12. Allegretti, M.; Bertini, R.; Cesta, M.C.; Bizzarri, C.; Di Bitondo, R.; Di Cioccio, V.; Galliera, E.; Berdini, V.; Topai, A.; Zampella, G.; Russo, V.; Di Bello, N.; Nano, G.; Nicolini, L.; Locati, M.; Fantucci, P.; Florio, S.; Colotta, F. 2-Arylpropionic CXC Chemokine Receptor 1 (CXCR1) Ligands as Novel Noncompetitive CXCL8 Inhibitors. J. Med. Chem. 2005, 48, 4312-4331. 
13. Li, H.; Hao, M.; Wang, L.; Liang, W.; Chen, K. Preparation of mono Boc-protected unsymmetrical diamines. Org. Prep. Proced. Int. 2009, 41, 301-307.

14. Lo, H.Y.; Bentzien, J.; Fleck, R.W.; Pullen, S.S.; Khine, H.H.; Woska, J.R.; Kugler, S.Z.; Kashem, M.A.; Takahashi, H. 2-Aminobenzimidazoles as potent ITK antagonists: trans-stilbenelike moieties targeting the kinase specificity pocket. Bioorg. Med. Chem. Lett. 2008, 18, 6218-6221.

15. McDonald, R.N.; Reineke, C.E. trans-1,2-Dihydrophthalic acid. Org. Synth. 1970, 50, 50-51.

Sample Availability: Contact the corresponding authors.

(C) 2010 by the authors; licensee MDPI, Basel, Switzerland. This article is an open access article distributed under the terms and conditions of the Creative Commons Attribution license (http://creativecommons.org/licenses/by/3.0/). 